\title{
Growth and intestinal morphology of juvenile pacu Piaractus mesopotamicus (Holmberg 1887) fed dietary prebiotics (mannanoligosaccharides - MOS)
}

\author{
RICARDO Y. SADO ${ }^{1}$, ÁLVARO J.A. BICUDO ${ }^{2}$ and JOSÉ E.P. CYRINO ${ }^{3}$ \\ ${ }^{1}$ Universidade Tecnológica Federal do Paraná, Campus de Dois Vizinhos, \\ Estrada para Boa Esperança, Km 04, 85660-000 Dois Vizinhos, PR, Brasil \\ ${ }^{2}$ Universidade Federal Rural de Pernambuco, Unidade Acadêmica de Garanhuns, \\ Avenida Bom Pastor, s/n, 55296-901 Garanhuns, PE, Brasil \\ ${ }^{3}$ Escola Superior de Agricultura "Luiz de Queiroz", Universidade de São Paulo, \\ Caixa Postal 9, 13418-900 Piracicaba, SP, Brasil
}

Manuscript received on March 25, 2013; accepted for publication on November 1, 2013

\begin{abstract}
Intensification of aquaculture production systems exposes fish to numerous stressors, which may negatively affect their growth and limit profitability of aquaculture systems. This study determined effects of increasing levels of dietary mannanoligosaccharides on growth and intestine morphology of pacu. Fish $(44.04 \mathrm{~g})$ were randomly distributed into 32 tanks (500 L; 10 fishes per tank) and fed during 63 days with a commercial diet supplemented with $0.0 ; 0.2 ; 0.4 ; 0.6 ; 0.8 ; 1.0 ; 1.5$ and $2.0 \%$ dietary mannanoligosaccharides. Growth parameters did not differ $(\mathrm{P}>0.05)$ between fish fed control diet and mannanoligosaccharide supplemented diets. Intestinal villi perimeter was performed in fish fed control diet, 0.4 and $1.5 \%$ dietary mannanoligosaccharides and also showed no differences $(\mathrm{P}>0.05)$ between treatments. Dietary supplementation of mannanoligosaccharides unclear did not have effects on pacu. Studies on the characterization of intestinal microbiota together with experiment that reproduce commercial fish production systems rearing conditions are necessary to determine the effective use of this dietary supplement for the species.
\end{abstract}

Key words: fish nutrition, histology, Piaractus mesopotamicus, prebiotics.

\section{INTRODUCTION}

Intensification of aquaculture production systems expose fish to numerous stressors such as poor water quality, crowding, handling and transport which may negatively affect their growth and health, and thus limit revenue of aquaculture systems (Gatesoupe 1999, Plumb 1999, Sakai 1999). In addition, fish farmers are now obliged to conform to Best Management Practices (BPMs) regulations

Correspondence to: Ricardo Yuji Sado E-mail: ricardoysado@utfpr.edu.br
(Boyd and Schmittou 1999, Boyd et al. 2005). This current setup favors the use of dietary prebiotics for management of farmed fish as an environmentally friendly practice. Attention to the use of these feed additives in fish farming is thus on the rise (Cuesta et al. 2002, Gatesoupe 1999, Kumari and Sahoo 2006, Sakai 1999). Nutrition plays an important role in the growth and health maintenance of fish (Merrifield et al. 2010), so the development of non-antibiotic and environmentally friendly feed supplements are key factors for fish growth and 
health management. In addition, because of the complex nature of aquatic culture systems, diversity of cultured species and pathogens, few antibiotics can be licensed for efficient and safe use (Qi et al. 2009). Therefore, there is an urgent need for the development of new alternatives to overcome the abuse of antibiotics.

Mannanoligosaccharides (MOS) are complex carbohydrates derived from yeast cell walls and present mannose as primary carbohydrate (Gouveia et al. 2006). This mannose, provides substrate for selective attachment of pathogenic intestinal bacteria, impairing bacterial adhesion to entherocytes, thus preventing infection of host cells, and leading to better gut health and integrity of gut villi (Gouveia et al. 2006).

Improved weight gain and survival rate have been reported for farm animals fed MOS supplemented diets (Newman and Newman 2001, Spring et al. 2000). Dietary MOS supplementation was studied in Mexico sturgeon Acipenser oxyrinchus desotoi (Pryor et al. 2003), Nile tilapia Oreochromis niloticus (Sado et al. 2008), rainbow trout Oncorhynchus mykiss (Staykov et al. 2007), European sea bass Dicentrarchus labrax (Torrecillas et al. 2007), channel catfish Ictalurus punctatus (Welker et al. 2007), tiger shrimp Penaeus semisulcatus (Genc et al. 2007), lobsters Homarus gammarus (Daniels et al. 2006, 2007), cobia Rachycentron canadum (Salze et al. 2008), and Atlantic salmon Salmo salar (GrisdaleHelland et al. 2008). Results can be deemed contradictory at best.

There are no reports on effects of dietary MOS on growth and intestine morphology of neotropical, freshwater teleosts. The omnivorous Characin pacu Piaractus mesopotamicus, native from the rivers, floodplains, lakes and flooded forest of Parana, Paraguay and Uruguay river basins is widely used in South American fish farming industry (Jomori et al. 2005, Urbinati and Gonçalves 2005). To date, no studies are found regarding the effects of dietary MOS supplementation for pacu. This study was set out to evaluate the effects of increasing levels of dietary MOS on the growth and intestinal morphology of pacu.

\section{MATERIALS AND METHODS}

Trials were set up in indoor, water recirculation system, with continuous aeration. Water quality parameters $(\mathrm{pH} 7.67 \pm 0.28$; dissolved oxygen 6.10 $\pm 0.77 \mathrm{mg} . \mathrm{L}^{-1}$; ammonia $\leq 0.5 \mathrm{mg} . \mathrm{L}^{-1}$; temperature $\left.28.7 \pm 1.76^{\circ} \mathrm{C}\right)$ remained within acceptable values for pacu (Urbinati and Gonçalves 2005). Juvenile pacus $(44.04 \pm 5.27 \mathrm{~g})$ were acclimatized to the experimental conditions for seven days, feeding on a $32 \%$ crude protein (CP) commercial feed. Then, the same commercial fish feed (Table I) was powdered, supplemented with $0.0,0.2,0.4,0.6,0.8$, 1.0, 1.5 and 2.0 of MOS (ActiveMOS - Biorigin ${ }^{\circledR}$, Lençóis Paulista, SP, Brazil), granulated and stored under refrigeration $\left(4^{\circ} \mathrm{C}\right)$.

TABLE I

Chemical composition of basal, practical diet (dry matter basis).

\begin{tabular}{cc}
\hline Nutrient & Content $(\%)$ \\
\hline Moisture & 5.13 \\
Crude protein & 27.43 \\
Crude fiber & 5.48 \\
Crude fat & 9.69 \\
Dry matter & 94.87 \\
Ash & 14.72 \\
\hline
\end{tabular}

Vitamin and mineral supplementation per $\mathrm{kg}$ of feed (from Purina do Brasil Ind. Com. Ltd., SP, Brazil): Mg, 700.0 mg; Fe, 100.0 mg; Cu, 15 mg; Zn, 200.0 mg; Mn, 30 mg; I, 1.0 mg; Se, $0.3 \mathrm{mg}$; vitamin $\mathrm{A}, 9,000 \mathrm{IU}$; vitamin $\mathrm{D}_{3}, 3,000 \mathrm{IU}$; vitamin $\mathrm{E}$, $112.0 \mathrm{IU}$; vitamin $\mathrm{K}, 7.50 \mathrm{IU}$; folic acid, $7.50 \mathrm{mg}$; biotin, 0.6 $\mathrm{mg}$; choline, $500.0 \mathrm{mg}$; niacin, $112.0 \mathrm{mg}$; calcium pantothenic, $37.0 \mathrm{mg}$; thiamin, $22.0 \mathrm{mg}$; riboflavin, $22.0 \mathrm{mg}$; pyridoxine, $22.0 \mathrm{mg}$; vitamin $\mathrm{B}_{12}, 26.0 \mu \mathrm{g}$; vitamin $\mathrm{C}, 150.0 \mathrm{mg}$.

After acclimation, fishes, were randomly assigned to 500-L polyethylene tanks (10 fish per group), each tank representing a replication of the following treatments $0.0,0.2,0.4,0.6,0.8$, $1.0,1.5$ and $2.0 \%$ of MOS in the diet, arranged 
in a completely randomized experimental design $(n=4)$. Fish were then fed with the experimental diets until apparent satiation twice a day $(0700 \mathrm{~h}$ and $1600 \mathrm{~h}$ ) for 63 days. At the end of the trial fish were fasted for $24 \mathrm{~h}$, anesthetized with alcoholic solution of benzocaine ( $\left.50 \mathrm{mg} . \mathrm{L}^{-1}\right)$ and sampled for biometrical and histological data.

Growth parameters of fish were evaluated according to Tacon (1990) as follows: Weight gain (WG=FW $-\mathrm{IW}$ ); Feed conversion ratio $(\mathrm{FCR}=$ feed consumption $\div$ weight gain); Daily feed consumption $(\mathrm{FC}=$ feed consumption $\div \mathrm{t}$ ); Specific growth rate $(\mathrm{SGR}=100 \times[(\operatorname{lnFW}-\ln \mathrm{IW}) \div \mathrm{t}])$. Where: $\mathrm{FW}=$ final weight $(\mathrm{g})$; IW=initial weight $(\mathrm{g})$; $\mathrm{t}=$ experimental time (days).

The proximal intestine fragment of two specimens from each replicate of 0.0 (control), 0.4 and $1.5 \%$ MOS supplemented diets was taken for histological observations. Tissue samples were immediately washed with saline solution $(0.6 \%)$ and fixed in a $4 \%$ paraformaldehyde in $0.1 \mathrm{M}$ phosphate buffer ( $\mathrm{pH}$ 7.2) and submitted to dehydration through alcohol solutions series (30 to $100 \%$ ). After dehydration process, tissues were pre-infiltrated in glycol metacrilate resin (JB-4, Polyscience Inc., Warrington, PA, USA) and $100 \%$ ethanol solution (1:1 proportion) for four hours and transferred to $100 \%$ resin solution until inclusion in plastic resin in histomoulds. The histological sections $(5 \mu \mathrm{m})$ were stained with haematoxylin and eosin ( $\mathrm{H} \& \mathrm{E})$ and documented photographically with a digital camera (Olympus DP71/12.5 megapixels, Japan) connected to a light microscope (Olympus BX51, Japan). The images were analyzed by using Image Pro Plus 6.1 software (Media Cybernetics Inc., Bethesda, MD, USA) for intestinal villi perimeter measures.

Results were submitted to statistical analysis of variance (ANOVA). Means showing significant differences were compared by $t$ test $(\alpha=0.05$ ) (Steel and Torrie 1980).

\section{RESULTS}

Growth parameters of fish fed MOS-supplemented diets did not differ $(\mathrm{P}>0.05)$ from that of fish fed control diet. Results are summarized in Table II. Dietary MOS supplementation (0.4 and 1.5\%) also did not significally affect total intestinal villi perimeter, although fish fed MOS-supplemented diets had higher absolute intestinal villi perimeter $(11673.6 \pm 2448 \mu \mathrm{m}$ and $10173.4 \pm 2439 \mu \mathrm{m}$ for 0.4 and $1.5 \%$ MOS supplementation, respectively) in comparison to fish fed control diet (8586.6 \pm $2428 \mu \mathrm{m})$ (Fig. 1).

TABLE II

Means and standard deviation (SD) of individual weight gain (WG), feed conversion rate (FCR), feed consumption (FC), specific growth rate (SGR) and survival rate (SR) of pacu, (P. mesopotamicus) fed increasing levels of dietary mannanoligosaccharide (MOS).

\begin{tabular}{cccccc}
\hline \multirow{2}{*}{ MOS* \% } & \multicolumn{5}{c}{ Individual } \\
\cline { 2 - 6 } & WG & FCR & FC g & SGR \% & SR \% \\
\hline 0.0 & $47.2 \pm 8.2$ & $2.0 \pm 0.04$ & $108.5 \pm 16.5$ & $1.0 \pm 0.21$ & 100 \\
0.2 & $45.4 \pm 3.7$ & $2.1 \pm 0.01$ & $95.8 \pm 7.3$ & $1.1 \pm 0.06$ & 100 \\
0.4 & $51.1 \pm 13.2$ & $2.1 \pm 0.21$ & $105.5 \pm 17.6$ & $1.2 \pm 0.22$ & 100 \\
0.6 & $45.1 \pm 6.8$ & $2.0 \pm 0.09$ & $92.9 \pm 9.9$ & $1.1 \pm 0.12$ & 100 \\
0.8 & $40.2 \pm 3.6$ & $2.1 \pm 0.14$ & $87.5 \pm 2.9$ & $1.0 \pm 0.05$ & 100 \\
1.0 & $58.7 \pm 6.3$ & $2.0 \pm 0.03$ & $117.8 \pm 13.1$ & $1.3 \pm 0.10$ & 100 \\
1.5 & $56.9 \pm 3.4$ & $2.0 \pm 0.07$ & $116.2 \pm 4.5$ & $1.3 \pm 0.06$ & 100 \\
2.0 & $50.0 \pm 8.1$ & $1.9 \pm 0.2$ & $96.2 \pm 17.4$ & $1.2 \pm 0.13$ & 100 \\
\hline ANOVA & 0.100 & 0.405 & 0.070 & 0.109 & \\
\hline
\end{tabular}

*Mannanoligosaccharide: ActiveMOS ${ }^{\circledR}$ (Biorigin, Lençóis Paulista, SP, Brazil). 


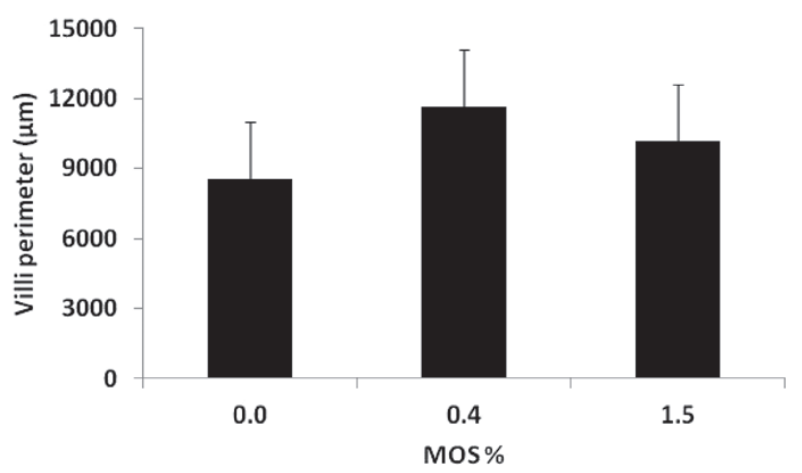

Figure 1 - Intestinal villi perimeter $(\mu \pm \mathrm{SD})$ of juvenile pacu (P. mesopotamicus) fed control diet, 0.4 and 1.5\% MOS supplemented diets for 63 days $(\mathrm{P}>0.05)$.

\section{DISCUSSION}

Several studies have shown that dietary prebiotics enhance growth and health (Burrells et al. 2001, Couso et al. 2003, Sakai 1999). Mannanoligosaccharides are a feature in farm animal nutrition (Ghosh and Mehla 2012, Newman and Newman 2001, Spring et al. 2000, Yalçinkaya et al. 2008). In aquatic animals, dietary MOS has only been recently used in an attempt to improve fish growth. Positive results on weight gain and immune response to dietary MOS were observed in rainbow trout, O. mykiss (Staykov et al. 2007), common carp Cyprinus carpio (Staykov et al. 2005), European sea bass Dicentrarchus labrax (Torrecillas et al. 2007), turbot Scophthalmus maximus (Li et al. 2008), tiger shrimp P. semisulcatus (Genc et al. 2007) and European lobster H. gammarus (Daniels et al. 2006, 2007) and crayfish Astacus leptodactylus (Mazlum et al. 2011). MOS are indigestible glucomannoproteins, providing mannose substrate upon which pathogenic gut bacteria selectively attach. Thereby, the inhibition of bacteria adhesion to enterocytes, prevents the formation of mixed colonies, the entrapment of nutrients for bacterial growth and the infection of host cells. This leads to better gut health by increasing regularity, height and integrity of the gut villi and a consequent better utilization and absorption of nutrients (Gouveia et al. 2006, Li et al. 2008, Pryor et al. 2003). However, the effects of dietary prebiotics in fish nutrition are still inconclusive.
Dietary MOS did not affect growth of pacu; identical results were recorded by Pryor et al. (2003) for Gulf of Mexico sturgeon fed $0.3 \%$ dietary MOS, Grisdale-Helland et al. (2008) for Atlantic salmon S. salar fed $1.0 \%$ dietary MOS, and by Dimitroglou et al. (2010a) for gilthead seabream Sparus aurata fed 0.2 and $0.4 \%$ dietary MOS. Growth of channel catfish Ictalurus punctatus fed $0.2 \%$ dietary MOS for six weeks did not differ from fish fed a control diet, although supplemented fish presented improved resistance when challenged by Edwardsiella ictaluri (Peterson et al. 2010). Nile tilapia fed 0.2, 0.4, 0.6; 0.8 and $1.0 \%$ dietary MOS for 45 days not only did not experience any improvement on growth parameters, but also had a negative correlation between dietary MOS supplementation and feed consumption (Sado et al. 2008).

Dietary MOS can enhance gut health by eliciting better intestinal villi development and increasing nutrient absorption area. Effects of dietary prebiotics on gut villi absorption area are well documented in poultry, swine and fish. Turkey fed MOS supplemented diets showed increased intestinal villi height and absorption area (Juskiewicz et al. 2002); however, sows and piglets fed dietary MOS at $0.1 \%$ supplementation for 77 days did not have significantly different villi height (Chiquieri et al. 2007).

Ultrastructural analysis of anterior intestine of Cobia larvae fed rotifers enriched with $0.2 \%$ MOS showed increased villi height (Salze et al. 2008). Similar observations were recorded for gilthead sea bream fed 0.2 and $0.4 \%$ dietary MOS (Dimitroglou et al. 2010a) and red drum Scianops ocellatus fed diets supplemented with $1 \%$ dietary prebiotics such as MOS, FOS and GOS (Zhou et al. 2010). However, in both cases, in spite of the fact that the ultrastructural analysis showed increased density of microvilli structures and length that could improve the potential of nutrient capture and absorption, dietary MOS did not influence the species' growth rate and feed utilization. White sea bream Diplodus sargus larvae 
fed artemia enriched with $0.2 \%$ MOS also showed improved intestinal villi surface (about 12\%) and length (Dimitroglou et al. 2010b), but no effects on performance of fish were reported by either authors.

Histological analysis carried out in this study revealed no differences $(\mathrm{P}>0.05)$ in intestinal villi perimeter between fish fed control diet and 0.4 and $1.5 \%$ MOS-supplemented diets. Pryor et al. (2003) did not find any significant difference in intestinal morphology of sturgeons fed $0.3 \%$ MOS supplementation for 28 days; similar results were reported by Torrecillas et al. (2007) for European seabass fed diets containing 0.2 and $0.4 \%$ MOS for 48 days. Feeding 0.2 and $0.4 \%$ dietary MOS to gilthead seabream did not result in differences in gross intestinal and liver histology (Dimitroglou et al. 2010a) and Genc et al. (2007) also did not report effects of dietary $\operatorname{MOS}\left(1.5,3.0\right.$ and 4.0 g. $\mathrm{kg}^{-1}$ diet) on hepatopancreas histology of tiger shrimp.

The purpose of using prebiotic in aquaculture is to enhance fish growth and increase disease resistance, improving economic viability of farming operations (Gatlin et al. 2008, Ringø et al. 2010). However, conflicting results demonstrated that the mode of action of these substances is still unclear, regarding time, dose and methods of administration, since time-dose response can cause negative effects.

Olsen et al. (2001), for instance, reported that brook trout Salvelinus alpinus fed diets containing $150 \mathrm{~g}$ inulin per kg presented damaged enterocytes and that feeding dietary inulin at 0.5 and $1.0 \%$ to gilthead sea bream Sparus aurata for seven days resulted in impaired leukocyte phagocytosis and respiratory burst (Cerezuela et al. 2008). Hybrid surubim Pseudoplatystoma sp. fed 0.5 and 1.0\% dietary inulin showed no effect on pathogenic bacteria population numbers when compared to fish fed control diet (Mouriño et al. 2012). In addition, Reza et al. (2009) feeding 1 to $3 \%$ dietary inulin to juvenile beluga, Huso huso for eight weeks observed impaired growth parameters compared to unsupplemented fish. Finally, European lobsters fed diets supplemented with 200 ppm MOS presented elevated mortality and impaired morphological development at juvenile phase (Daniels et al. 2006).

The use of prebiotics as mannanoligosaccharides to improve growth and health status in fish still needs further research for better explanation of contradictory results. The complex carbohydrate structure in the cell wall of yeast, the different strains, fermentation conditions and processing methods can all alter their function (Newman 2007) as well as different ingredients used in diet formulation can widely vary among different fish species (Yousefian and Amiri 2009). Moreover, depending on MOS concentration, administration period, hearing condition and population status (age, sex, gonadal maturation) (Pryor et al. 2003) different results can be obtained.

The present study was performed in controlled laboratory hearing conditions. Thus, the higher water microorganisms concentrations and the ambient variation, normally observed in intensive fish production that continuously challenge fishes, were not reproduced. Therefore, experiment condition can be an additional relevant factor for contradictory results found in literature and in the present study.

\section{CONCLUSION}

Dietary MOS supplementation did not positively affect growth and intestinal morphology of pacu. Results recorded to date are nothing but contradictory, thus studies regarding pacu's gut microbiota characterization and experiment that reproduce commercial fish production systems hearing conditions are necessary to determine the mode of action and the most effective use of this supplement as prebiotic for the species.

\section{ACKNOWLEDGMENTS}

The authors would like to thank Biorigin (Lençois Paulista, SP, Brazil) for providing the tested feed supplement-ActiveMOS ${ }^{\circledR}$, and Fundação de Amparo à Pesquisa do Estado de São Paulo (FAPESP) for doctoral scholarships granted to RY Sado (Proc. 
05/51967-2) and AJA Bicudo (Proc. 05/51968-9). JEP Cyrino is a Conselho Nacional de Desenvolvimento Científico e Tecnológico (CNPq) research scholar.

\section{RESUMO}

A intensificação dos sistemas de produção em aquicultura expõe os peixes a inúmeros estressores, os quais afetam negativamente seu crescimento e limitam a rentabilidade dos sistemas de aquicultura. Este estudo determinou o efeito de níveis crescentes de mananoligossacarídeos dietéticos sobre o crescimento e morfologia intestinal do pacu. Os peixes $(44,04 \mathrm{~g})$ foram aleatoriamente distribuídos em 32 tanques ( $500 \mathrm{~L}$; 10 peixes por tanque) e alimentados por 63 dias com uma dieta comercial suplementada com 0,0 ; 0,$2 ; 0,4 ; 0,6 ; 0,8 ; 1,0 ; 1,5$ e 2,0\% de mananoligossacarídeo dietético. Os parâmetros de crescimento não diferiram $(P>0,05)$ entre os peixes alimentados com a dieta controle e as dietas suplementadas com mananoligossacarídeo. O perímetro das vilosidades intestinais foi realizado nos peixes alimentados com a dieta controle, $0,4 \mathrm{e}$ $1,5 \%$ de mananoligossacarídeos dietéticos e também não apresentaram diferenças $(\mathrm{P}>0,05)$ entre os tratamentos. A suplementação dietética de mananoligassarídeos não teve efeito no pacu. Estudos relacionados à caracterização da microbiota intestinal e experimento que reproduz sistemas comerciais de produção de peixes são necessários para determinar o uso efetivo deste suplemento dietético para a espécie.

Palavras-chave: nutrição de peixes, histologia, Piaractus mesopotamicus, prebióticos.

\section{REFERENCES}

Boyd CE, McNevin AA, Clay J And Johnson HM. 2005. Certification issues for some common aquaculture species. Rev Fish Sci 13: 231-279.

Boyd CE AND SchmitTou HR. 1999. Achievement of sustainable aquaculture through environmental management. Aquacult Econ Manag 3: 59-69.

BurRells C, Willians PD AND Forno PF. 2001. Dietary nucleotides: a novel supplement in fish feeds. Effects on resistance to disease in salmonids. Aquaculture 199: 159-169.

Cerezuela R, Cuesta A, Meseguer J and Esteban MA. 2008. Effects of inulin on gilthead seabream (Sparus aurata L.) innate immune parameters. Fish Shellfish Immun 24: 663-668.
Chiquieri J, SOARES RTRN, Nery VLH, CARVAlHo ECQ AND COSTA APD. 2007. Blood biochemical and height of intestinal vilosity of swine feed supplemented with probiotic, prebiotic and antibiotic. Rev Bras Saúde Prod Anim 8: 97-104.

Couso N, CAstro R, Magariños B, OBACH A AND LAMAS J. 2003. Effect of oral administration of glucans on the resistance of gilthead seabream to pasteurellosis. Aquaculture 219: 99-109.

Cuesta A, Esteban MA And Meseguer J. 2002. Levamisole is a potent enhancer of gilthead seabream natural cytotoxic activity. Vet Immunol Immunopathol 89: 169-174.

Daniels C, Boothroyd D, Davies S, Pryor R, TAYlor D AND Wells C. 2006. Bio-Mos ${ }^{\circledR}$ improves growth and survival of cultured lobsters. Shellfish News 21: 23-25.

Daniels C, BoOthroyd D, DAVIES S, PRYOR R AND Wells C. 2007. Developing and understanding the use of pre-biotics in homarid lobster culture. Aquacult Health Int 8: 32-35.

Dimitroglou A, Davies SJ, Sweetman J, Divanach P AND CHATZIFOTIS S. 2010b. Dietary supplementation of mannan oligosaccharide on white sea bream (Diplodus sargus L.) larvae: effects on development, gut morphology and salinity tolerance. Aquacult Res 41: 245-251.

Dimitroglou A, Merrifield DL, Spring P, SweEtman J, MoATE R AND DAVIES SJ. 2010a. Effects of mannan oligosaccharide (MOS) supplementation on growth performance, feed utilization, intestinal histology and gut microbiota of gilthead sea bream (Sparus aurata). Aquaculture 300: 182-188.

GATESOUPE FJ. 1999. The use of probiotics in aquaculture. Aquaculture 180: 147-165.

Gatlin DM, Burr G, Li P And Buentello A. 2008. Prebiotic application in aquaculture for health management. Int Aquafeed: 18-21.

Genc MA, AKTAS M, GENC E AND YiLmaz E. 2007. Effects of dietary mannan oligosaccharide on growth, body composition and hepatopancreas histology of Penaeus semisulcatus (de Haan 1844). Aquacult Nutr 13: 156-161.

GHOSH S AND MEHLA RK. 2012. Influence of dietary supplementation of prebiotics (mannanoligosaccharide) on the performance of crossbred calves. Trop Anim Health Prod 44: 617-622.

Gouveia EMF, SILVA IS, ONSELEM VJV, CORREA RAC AND SILVA CJ. 2006. Use of mannanoligoscharides as an adjuvant treatment for gastrointestinal diseases and its effects on E. coli inactivated in dogs. Acta Cir Bras 21: 23-26.

Grisdale-Helland B, Helland SJ AND Gatlin DM. 2008 The effects of dietary supplementation with mannanoligosaccharides, fructooligosaccharide on the growth and feed utilization of Atlantic salmon (Salmo salar). Aquaculture 283: 163-137.

JOMORI RK, CARNEIRo DJ, MARTINS MIEG AND PORTELla MC. 2005. Economic evaluation of Piaractus mesopotamicus juvenile production in different rearing systems. Aquaculture 243: 175-183. 
JUSKIEWICZ J, ZDUNCZYK Z, JANHOWSKI J AND KRÓL B. 2002. Caecal metabolism in young turkeys fed diets supplemented with oligosaccharides. Arch Geflügelk 66: 206-210.

KUMARI J AND SAHOO PK. 2006. Dietary $\beta-1,3$ glucan potentiates innate immunity and disease resistance of Asian catfish, Clarias batrachus (L.). J Fish Dis 29: 95-101.

LI Y, WANG YJ, WANG L AND JiANG KY. 2008. Influence of several non-nutrient additivies on nonspecific immunity and growth of juvenile turbot, Scophthalmus maximus L. Aquacult Nutr 14: 387-395.

Mazlum Y, Yilmaz E, Genç MA And Guner O. 2011. A preliminary study on the use of mannan oligosaccharides (MOS) in freshwater crayfish, Astacus leptodactylus Eschscholtz, 1823 juvenile diets. Aquacult Int 19: 111-119.

Merrifield DL, Dimitroglou A, Foey A, Davies SJ, Castex J AND RINGø E. 2010. The current status and future focus of probiotic and prebiotic applications for salmonids. Aquaculture 302: 1-18.

Mouriño JLP, NASCIMENTO VIEIRA F, JATOBÁ AB, SILVA BC, JESUS GFA, SEIFFERT WQ AND MARTINS ML. 2012. Effects of dietary inulin and $W$. cibaria on haemato-immunological parameters of hybris surubim (Pseudoplatystoma sp.). Aquacult Nutr 18: 73-80.

NEWMAN K. 2007. Form follows function in picking MOS product. Feedstuffs 79: 1-2.

NEWMAN KE AND NEWMAN MC. 2001. Evaluation of mannan oligosaccharide on the microflora and immunoglobulin status of sows and piglet performance. J Anim Sci 79: 189.

OLSEN RE, MyKleBUST R, KRYVi H, MAYHEW TM AND RINGø E. 2001. Damaging effect of dietary inulin on intestinal enterocytes in Artic charr (Salvelinus alpinus L.). Aquacult Res 32: 931-934.

Peterson BC, Bramble TC and Manning BB. 2010. Effects of Bio-Mos ${ }^{\circledR}$ on Growth and Survival of Channel Catfish Challenged with Edwardsiella ictaluri. J World Aquacult Soc 41: 149-155.

PlumB JA. 1999. Health maintenance and principal microbial diseases of cultured fishes. Ames: The Iowa State University Press.

Pryor GS, Royes JB, Chapman FA AND Miles RD. 2003. Mannanoligosaccharides in fish nutrition: effects of dietary supplementation on growth and gastrointestinal villi structure in Gulf of Mexico Sturgeon. N Am J Aquacult 65: 106-111.

Qi Z, Zhang XH, BoOn N AND Bossierd P. 2009. Probiotics in aquaculture of China - Current state, problems and prospect. Aquaculture 290: 15-21.

Reza A, AbDolmajid H, AbBas M and AbDolmohammad AK. 2009. Effect of Dietary Prebiotic Inulin on Growth Performance, Intestinal Microflora, Body Composition and Hematological Parameters of Juvenile Beluga, Huso huso (Linnaeus, 1758). J World Aquacult Soc 40: 771-779.

Ringø E, Olsen RE, Gifstad TO, DALmo RA, AmLund H, Hemre GI AND BAKKe AM. 2010. Prebiotics in aquaculture: a review. Aquacult Nutr 16: 117-136.
SADO RY, BICUDO AJA AND CYRINO JEP. 2008. Feeding dietary mannan oligosaccharides to juvenile Nile tilapia, Oreochromis niloticus have no effect on hematological parameters and showed decreased feed consumption. J World Aquacult Soc 39: 821-826.

SAKAI M. 1999. Current research status of fish immunostimulants. Aquaculture 172: 63-92.

Salze G, Mclean E, Schwarz MH ANd Craig SR. 2008. Dietary mannan oligosaccharide enhances salinity tolerance and gut development of larval cobia. Aquaculture 274: $148-152$.

Spring P, Wenk C, Dawson KA AND NeWMan KE. 2000. The effects of dietary mannanoligosaccharides on cecal parameters and the concentrations of enteric bacteria in the ceca of salmonella-challenged broiler chicks. Poultry Sci 79: 205-211.

STAYKOV Y, DENEV S AND SPRING P. 2005. Influence of dietary mannan oligosaccharides (Bio-Mos ${ }^{\circledR}$ ) on growth rate and immune function of common carp (Cyprinus carpio L.). In: Howal B and Flos R (Eds), Lessons from the past to optimize the future. Eur Aquacult Soc 35: 431-432.

STAYKov Y, SPRING P, DENEV S AND SWEETMAN J. 2007. Effect of mannan oligosaccharide on the growth performance and immune status of rainbow trout (Oncorhynchus mykiss). Aquacult Int 15: 153-161.

STEEL RGD AND TORRIE JH. 1980. Principles and procedures of statistics: a biometrical approach. $2^{\text {nd }}$ ed., New York: McGraw-Hill.

TACON AGJ. 1990. Standard methods for the nutrition of farmed fish and shrimp. Seattle: Argent Laboratories Press.

Torrecillas S, Makol A, Caballero RJ, Montero D, ROBAINA L, REAL F, SWEETMAN J, TORT L AND IZQUIERDO MS. 2007. Immune stimulation and improved infection resistance in European sea bass (Dicentrarchus labrax) fed mannan oligosaccharides. Fish Shellfish Immunol 23: 969-981.

Urbinati EC AND GonçAlves FD. 2005. Pacu (Piaractus mesopotamicus). In: Baldisserotto B and Gomes LC (Eds), Espécies nativas para piscicultura no Brasil. Editora UFSM, Santa Maria, RS, Brasil, p. 225-255.

WelKer TL, LIM C, YILDRIM-AKSOY M, SHELBY R AND KLESIUS PH. 2007. Immune responses and resistance to stress and Edwardsiella ictaluri challenge in channel catfish, Ictalurus punctatus, fed diets containing commercial whole-cell yeast or yeast subcomponents. J World Aquacult Soc 38: 24-35.

YALÇINKAYA I, GÜNGÖR T, BASALAN M AND ERDEM E. 2008. Mannan oligosaccharides (MOS) from Saccharomyces cerevisiae in broilers: effects on performance and blood biochemistry. Turk J Vet Anim Sci 32: 43-48.

YOUSEFIAN M AND AMIRI MS. 2009. A review of the use of prebiotic in aquaculture for fish and shrimp. Afr $\mathrm{J}$ Biotechnol 8: 7313-7318.

ZHOU QC, BuENTELlo JA AND GATLIN DM. 2010. Effects of dietary prebiotics on growth performance, immune response and intestinal morphology of re drum (Sciaenops ocellatus). Aquaculture 309: 253-257. 
